\title{
Robots Don't Pay Taxes: Deindustrialization and Fiscal Decline
}

Abstract: Deindustrialization has fundamentally reshaped the economic geography of the United States. Between 1993 and 2007 alone, increasing automation - the use of industrial robots to perform tasks done by human workers-led to the loss of upwards of 750,000 jobs, primarily in the industrial Midwest and Northeast. Prior research demonstrates the social consequences of manufacturing's decline extend beyond its impact on workers to undermine the health and economic prospects of entire communities. But through which mechanisms? This study examines the impact of increasing automation on local government finance. Exploiting spatial variation in the adoption of industrial robots, we find each additional robot per 1,000 workers is associated with a 10 percent relative decline in local government own-source revenues, a decline that is only partially offset by intergovernmental transfers. Moreover, we find that each robot per 1,000 workers leads to an 8 percent decline in K-12 education spending and a 30 percent decline in health spending. Our findings provide direct evidence of an oft-theorized but rarely examined mechanism through which place directly shapes life chances. We use our theoretical framework to motivate a Fiscal Sociology of place that centers the role of fiscal structures in the production of place-based inequalities.

Key Words: Deindustrialization; Inequality; Public Policy; Technology

\author{
Rourke O'Brien* \\ Yale University \\ Zachary Parolin \\ Bocconi University
}

Atheendar Venkataramani

University of Pennsylvania

Acknowledgements: The authors thank seminar participants at Yale University, Seoul National University, the WZB Berlin Social Science Center, the Northwestern Problem Solvers Workshop and the Society for the Advancement of Socio-Economics (SASE) for helpful comments and suggestions. The authors would also like to thank Noah Friedlander, Bessie Bauman, Michael Martinez, Harrison Bushnell, and Aria Harris for valuable research assistance.

*Direct all correspondence to 493 College St New Haven, CT 06510; (203) 436-4014; rourke.obrien@yale.edu 
The economy of the United States (U.S.) has undergone a massive restructuring in recent decades. From 1980 to 2020 the share of workers employed in a goods-producing industry fell from one in four to just one in ten (Seltzer 2020; Fort, Pierce \& Schott 2018). This structural shift is the result of multiple factors (Kollmeyer 2009; Alderson 1999; Brady \& Denniston 2006) including competition from foreign trade and the adoption of new technologies, particularly the use of industrial robots to automate tasks previously done by human workers. Between 1993 and 2007 the stock of industrial robots increased by fourfold in the U.S., resulting in an estimated loss of between 400,000 and 750,000 jobs over just this 15-year period (Acemoglu \& Restrepo 2020).

A bevy of recent social science research reveals how deindustrialization is reshaping nearly every facet of American social life, from fertility and marriage to employment and wages to health and political polarization (Wilson 1987, 1994; Autor, Dorn \& Hanson 2019; Fort et al 2018; Acemoglu \& Restrepo 2020; Autor, Dorn \& Hanesen 2020; Kollmeyer 2018; Kollmeyer \& Pichler 2013). Population health researchers point to the decline of manufacturing jobs as a key driver of increasing 'deaths of despair' due to alcohol, drugs and suicide, particularly among males without a college degree (Case \& Deaton 2017; Seltzer 2020; O’Brien, Bair and Venkataramani 2021). Scholars of inequality reveal how deindustrialization has fundamentally reshaped the spatial distribution of economic opportunity; three recent studies (Seltzer 2021; Connor \& Storper 2020; Berger \& Engzell 2020) demonstrate manufacturing job loss is a key driver of declining intergenerational economic mobility, particularly in the industrial Midwest.

Social scientific examinations of deindustrialization typically take an ecological view, theorizing implicitly or explicitly that the negative effect of manufacturing's decline extends well beyond its direct impact on manufacturing workers or 'would be' workers. By what mechanisms does the decline of the manufacturing sector serve to undermine the health, well-being and 
economic prospects of entire communities? One oft-asserted explanation is the erosion of local tax bases and resulting decline in government spending that serves to compound the harmful social effects of concentrated joblessness and disadvantage; extending Wilson's $(1987,1994)$ structural analysis of the plight of the inner-city poor to the decaying industrial heartland (see, e.g., Brady \& Wallace 2001; Russo \& Linkon 2009; Gould 2020; Autor et al 2020).

Yet it remains an open question whether and to what extent automation-driven deindustrialization impacts public sector revenues. On the one hand, industrial robots displace workers, reducing overall employment and wages (Acemoglu and Restrepo 2020; Autor and Salomons 2018); factors which may on net contribute to weaker tax bases and lower government revenues. On the other hand, industrial robots increase manufacturing productivity, reducing the cost of tradable goods and increasing the income returns to capital; factors which on net may result in higher government revenues. Moreover, fiscal transfers from state governments to local governments may offset any automation-induced losses to local governments' tax bases.

In this paper we ask: What is the effect of automation-driven deindustrialization on local government revenues? And to what extent do fiscal transfers from state and federal governments serve to mitigate this impact?

To identify the causal effect of automation-driven deindustrialization on public finances, we employ a modified version of the empirical strategy developed by Acemoglu and Restrepo (hereafter A\&R) (2020) that exploits trends in the adoption of industrial robots across industries in Europe-where automation outpaced the United States - to construct a measure of predicted adoption of industrial robots across U.S. commuting zones during the 1990s and 2000s that is exogenous to local labor market trends. We combine this measure with data on local government public finances from the U.S. census of governments to estimate the effect of increasing 
automation on local government finances in a series of first difference models. Given meaningful cross-state heterogeneity in the structure of fiscal governance, our primary specification includes state fixed effects to focus on how increasing automation affects the change in revenues and expenditures across local governments in the same state.

We find that the rise of automation drove substantial relative declines in local government own source revenue over the study period. Point estimates indicate that every additional robot per 1,000 workers in the commuting zone between 1993 and 2000 was associated with a 10 percent relative decline in local government own source revenue between 1992 and 2002. This estimated effect is large and consistent with the sharp declines in employment and average wages per robot estimated by A\&R. Sensitivity analyses affirm our results are robust to different time horizons and are not being driven by trends in the automotive industry, the sector that experienced by far the largest increase in automation in recent decades, or pre-existing trends in area-level finances.

We go on to examine whether and to what extent fiscal transfers from higher levels of government serve to offset this hit to local government revenues. We find the negative effect on own source revenues is only partially mitigated by increased intergovernmental transfers, resulting in a 5 percent decline in local government per capita expenditures. We then examine the effect of automation on expenditures by category, focusing on key functions of local governments including K-12 education, health, police protection and public welfare. We find substantively large and statistically significant negative impacts on health and K-12 education spending: point estimates indicate that every additional robot per 1,000 workers between 1993 and 2000 is associated with a 30 percent relative decline in health and hospital spending per capita and an 8 percent relative decline in K-12 education spending per capita. 
Of course, a reduction in K-12 per capita spending does not necessarily translate into a reduction in per pupil spending, the operative margin. We therefore supplement our analysis of Census of Government public finance data with measures of school finance from the National Center for Education Statistics. From these data we estimate that each additional robot per 1,000 workers results in a 11 percent drop in local school funding per student. Transfer revenue from state and federal governments mitigates some but not all of this decrease, on net resulting in a relative decline in per student revenues and expenditures of about 3 percent per additional robot.

Our study makes several contributions. First, we demonstrate a causal, negative effect of technological-driven deindustrialization on local government own source revenues. Second, we show that transfers from higher levels of government fail to offset the hit to local government coffers, illustrating how the structure of U.S. fiscal federalism — an international outlier in failing to equalize resources across jurisdictions - exacerbates place-based disparities. Third, we 'follow the money' and reveal that lost revenue translates into reduced government expenditures, particularly investments in health and elementary and secondary education. In so doing, we provide first order evidence of the oft-theorized 'spillover effects' through which the forces of deindustrialization serve to harm the well-being of entire communities, as evidenced by declining rates of mobility and increasing mortality. Finally, our approach advances the theoretical project of the New Fiscal Sociology (Martin, Mehrota and Prasad 2009) by revealing the role of how fiscal structures are implicated in the production of spatial inequalities and may be a key site for novel policy solutions to pressing social problems (Prasad 2018). 


\section{Fiscal Sociology and Place-Based Inequality}

A recurring theme in the social science of poverty and inequality is the relevance of place. Comparative welfare state research, for example, reveals how cross-national variation in wealth, institutions, politics and policy explain observed differences in poverty, inequality, and social outcomes from fertility and mortality to human capital attainment and labor market performance (see, e.g., Beckfield and Bambra 2016; Brady 2009; Esping-Andersen 1990). At the other geographic extreme, decades of social science research from Wilson $(1987,1996)$ to Massey \& Denton (1993) to Sampson (2008) to Patillo (2013) and others have demonstrated that, quite simply, neighborhoods matter. Neighborhood context has been found to impact health, human capital attainment, labor market performance, and overall well-being (Sharkey 2008; Sampson 2019). In recent years, researchers have documented the causal effect of exposure to meso-level places, such as county (Chetty \& Hendren 2018) or state (Montez et al 2019; Montez et al 2020) of residence, on life chances. Moreover, there is growing consensus that exposure to place during critical periods of childhood and early adolescence has lasting, measurable effects on individual outcomes over the life course (Chetty, Hendren and Katz 2016). Children who grow up in areas of disadvantage — due to concentrated joblessness, poverty, segregation—on average do worse than their peers raised in more advantaged communities (Sharkey and Faber 2014).

By what mechanisms does place so profoundly shape life chances? How does growing up in an area with high rates of joblessness undermine well-being and stymie potential? Beyond social effects of concentrated disadvantage (Wilson 1996), scholars routinely point to underfunded public sectors as one structural mechanism through which place-based inequalities are reinforced, reproduced and even amplified (see, e.g., Massey 1990 p. 351). And with good reason: a broad 
body of empirical research across the social sciences concludes government spending is a key determinant of place-based variation in social outcomes.

Yet despite its frequent and reasonable invocation as a mechanism of place, sociologists rarely examine explicitly how fiscal structures are implicated in the production of place-based inequalities and their evolution over time. Sociological analyses of taxation and inequality instead focus primarily on how taxation shapes the distribution of income or the degree of household poverty (e.g., Allen and Campbell 1994). For example, in Martin and Prasad's (2014) review of the empirical literature on taxation and social inequality in wealthy countries, every study cited examines either 1 . The effect of taxation on the level or intensity of income inequality, 2 . The effect of tax-based incentives (and disincentives) on the behavior of individuals and firms, or, 3 . The effects of tax-based social transfers, such as the Earned Income Tax Credit (EITC), on poverty and poverty-related outcomes. What we miss by focusing exclusively on how taxation shapes inequality between people is how taxation shapes inequality between places.

Appreciating how taxation and, more generally, the structure of fiscal systems is implicated in the production of place-based inequalities is particularly important in the U.S. context for several reasons. First, subnational governments in the U.S.—-states, counties, cities, school districts and other spatially circumscribed fiscal units such as 'special taxing districts'—play a central role in the provision of public goods, spending \$3.2 trillion in 2018 alone. More than half of that spending ( $\$ 1.7$ trillion) was done by local governments, primarily on K-12 education and other social investments such as health, public welfare and police (Urban Institute 2021). Detailing whether and to what extent automation, or other macroeconomic forces, impacts local public sectors is therefore key to capturing the total impact on communities. 
Second, the U.S. is the only federal democracy without a fiscal equalization scheme explicitly designed to reduce disparities in fiscal capacity across subnational units (Béland and Lecours 2014; McCabe 2017). The federal government makes substantial direct transfers to state and, to a lesser extent, local governments: a total of \$721 billion in 2019 accounting for about 25 percent of all state and local revenues (Tax Policy Center 2021). However, these dollars, transferred via block grants or categorical grants, often require state and local governments to contribute matching funds and, at the same time, the formulas used to allocate resources often fail to fully account for differences in fiscal capacity (see, e.g., the Medicaid program). This results in wealthier states with higher tax resource bases-such as California, New York and Massachusetts - often receiving more federal dollars per capita than poorer states such as Alabama or New Mexico. Without federal dollars to compensate for their weaker tax bases - and with the statutory obligations to balance budgets and refrain from deficit spending-residents of states hit hard by the forces of deindustrialization must either shoulder a higher tax burden or suffer more anemic public spending than residents of wealthier states.

Just as the federal government fails to equalize fiscal resources across states, states often fail to equalize fiscal resources across local jurisdictions. The degree of fiscal redistribution and equalization is determined by many factors. For one, states vary markedly in the extent to which the state government versus local governments is responsible for taxing and spending; this 'fiscal centralization' in revenue ranges from a low of 42 percent in Nebraska to a high of 79 percent in Vermont. ${ }^{1}$ A second factor is the structure of school finance. After more than a century of policy

\footnotetext{
${ }^{1}$ An alternative is to operationalize fiscal centralization as the percentage of all state and local expenditures made by the state government--ranging from 47 percent in Nebraska to 85 percent in New Mexico. This wide variation in fiscal centralization is the result of historically conditioned differences in the structure of fiscal governance including the disparate allocation of revenue powers and spending responsibilities across different levels of government.
} 
evolution and litigation - appealing to the enumerated right to education etched in many state constitutions - today virtually every state has an explicit policy schema designed to reduce placebased disparities in education finance. This is typically accomplished through intergovernmental transfers designed to offset differences in the wealth of local tax bases and is implemented via school finance equalization formulas, flat grants to guarantee a certain amount of spending per pupil, or other strategies. Importantly, these approaches are not all equally effective and, in some instances, states achieve more equality in school finance by 'leveling down' wealthier districts rather than 'leveling up' poorer ones (Hoxby 2001).

The third motivation for a fiscal sociology of place is that place-based inequality is increasing in the United States. After substantial convergence over much of the 20th century, today the wealth of states - and, to a greater extent, the wealth of local jurisdictions such as cities, counties, and school districts—is becoming more unequal (Amos 2014; Ganong and Shoag 2017; Nunn \& Shambaugh 2018). Increasing concentration of wealth, capital, and high-paying jobs on the coasts and in urban areas pushes those communities further ahead as rural communities and the industrial heartland fall further behind. As Manduca reveals (2019), a byproduct of increasing income concentration among rich people has been a dramatic increase in inequality between places; according to his research, the percentage of Americans who live in a metro area that is either substantially poorer or richer than average has nearly tripled since 1980 . These trends are also increasingly reflected in our politics, as the divergent trajectories of rich and poor areas (urban and rural, red and blue) is a defining cleavage of national discourse.

Finally, analyzing the role of fiscal structures in reflecting and reproducing place-based inequalities is key to accurately diagnosing the structural determinants of inequality and targeting the right level for policy intervention. Increasing spatial inequality in the U.S. is primarily the 
result of larger structural forces of globalization and technological change, not the byproduct of local policy decisions (Manduca 2019; Ganong and Shoag 2017). Yet much of our policy conversation places the blame for community decline at the feet of local policymakers; for example, by failing to adequately 'incentivize' private sector investment (Bartik 2019). Revealing how exogenous forces — such as the rise of automation — affect the level and distribution of public sector resources is a critical first step towards a more productive conversation about what is owed to communities that are left behind. And how we might change our fiscal structures to ensure that communities suffering from widespread job loss in the face of deindustrialization, or another macroeconomic trend, can continue to have robust public sectors.

\section{Deindustrialization and Community Decline}

The social and economic effects of deindustrialization are far reaching. Manufacturing job loss stemming from plant closures or downsizing leaves a lasting scar on workers who suffer from reduced employment and wages as well as worse physical and mental health outcomes (see Brand 2015 for a review).

But it's not just laid off workers who bear the brunt of manufacturing decline. Study after study details the negative effects of deindustrialization on entire communities. For example, a recent spate of studies reveals the decline in manufacturing has fundamentally reshaped the structure of opportunity in America. Examining the changing spatial pattern of economic mobility in the U.S., Connor and Storper (2020) find that intergenerational economic mobility declined substantially in the industrial northeast and Midwest in recent decades, attributed in part to the loss of manufacturing jobs that once dominated the area and served as a key pathway to upward mobility. Examining the upward mobility outcomes of adjacent cohorts in the same community, 
Seltzer (2020) finds that the number of manufacturing jobs at the time a cohort enters the labor force is positively associated with climbing the income ladder in early adulthood. Looking specifically at the effects of automation, Berger and Engzell (2020) find a large and negative effect of robot penetration in the commuting zone and upward mobility, particularly for white men.

This observed spatial variation in economic opportunity is driven in part by variation in local government spending. Biasi (2019), for example, finds compelling evidence that K-12 school funding, in particular, is a major driver of intergenerational economic mobility. Leveraging variation in school finance due to 13 reforms passed in 20 states between 1986 and 2004, she finds that equalizing school funding across jurisdictions led to a substantial increase in the upward mobility of treated cohorts when measured in adulthood. The effect was largest for students from low-income households. This finding is consistent with work showing a positive, causal effect of K-12 education spending on student outcomes, including eventual educational attainment, wages and reduced poverty in adulthood (Jackson, Johnson, Persico 2016). It is also consistent with earlier work by Mayer and Lopoo (2008) who use the PSID to show that intergenerational mobility is greater in high-spending states relative to low-spending states.

A parallel story is emerging in the field of population health, where deindustrialization is contributing to not only the overall decline in longevity — driven by rising 'deaths of despair' (Case and Deaton 2018)-but also increasing spatial variation in health outcomes. For example, manufacturing job loss has been linked to increased mortality in studies examining both acute shocks stemming from plant closure (Sullivan \& von Wachter 2009; Venkataramani et al 2020; Browning \& Heinsen 2012) as well as those examining long-run trends including the rise of automation (O'Brien et al 2021; Charles, Hurst, Schwartz 2018; Seltzer 2020). Here, too, the impact of deindustrialization on government spending is asserted as one pathway through which 
manufacturing decline impacts the broader community; an assertion firmly supported by empirical evidence identifying public sector expenditures as a key determinant of health outcomes (see, e.g., Bradley et al 2016).

Given broad empirical support for the idea that government spending matters for social outcomes, it is reasonable for analysts of deindustrialization to point to weakened public sectors as one potential pathway through which manufacturing job loss undermines the health and opportunity of entire communities. Yet to our knowledge the only empirical examination of this potential mechanism is by Feler and Senses (2017) who examine the impact of exposure to foreign trade competition, a key driver of manufacturing decline in many communities. They find that foreign trade competition from China-which resulted in a decline in local income, business activity and housing values-led to a decline in local government revenues and expenditures on key public services such as education. Our analysis builds on this work by examining the impact of deindustrialization induced by technological change, in the form of industrial robots, on local government public finances.

\section{The Fiscal Effects of Automation}

How might the rise of industrial robots impact local government finance? Local governments rely on multiple sources of revenue to fund the public sector. The first is 'own source revenue', that is, revenue collected by local governments from levying their own taxes and fees. The mix of revenue instruments varies substantially_due to in part to differences in legal authority and administrative capacity-but includes some mix of: property taxes (residential and commercial), personal income taxes, sales \& excise taxes on goods and/or services, corporate net 
income or 'profit' taxes, and myriad fines \& fees for everything from parking tickets to school lunch fees to special assessments for sidewalk improvements.

There are three main pathways through which industrial automation may mechanically impact local government own source revenues. First, if automation displaces workers and on net reduces total income by lowering the employment rate and/or average wages we should expect this to result in lower revenues from income and consumption taxes. Second, automation could impact local revenues by increasing net corporate income. Replacing workers with robots should reduce the cost of tradable goods and increase profits for corporations: increased corporate profits may yield increased revenues via the corporate income tax or via the personal income tax when profits are distributed as income to the owners of capital. Third, the rise of automation and resulting job loss may in turn weaken the value of commercial and/or residential property subject to property taxes, thereby reducing revenue receipts.

A\&R (2020) found that an increase of one robot per 1,000 workers in a commuting zone results in a decline in the employment to population ratio of 0.39 percentage points and a decline in average wages of 0.77 percentage points. This is a substantial decline in local income and purchasing power. Even if this loss to total income was accompanied by an uptick in corporate profits, any increase in corporate tax revenue is unlikely to compensate for revenue lost elsewhere. For one, corporate profit taxes make up a small fraction of total state and local revenue nationally, with the vast majority of that captured by state governments. Capital income is a relatively small fraction of total income, is rarely taxed directly at the local level, and even in most states receives preferential treatment in the income tax code (relative to wages). Moreover, taxes are place-based and it is unlikely the headquarters of a manufacturing company and the owners of capital even reside in the same fiscal jurisdiction experiencing the job loss; any gains that accrue to these 
entities may translate into positive tax revenue for another jurisdiction. On balance, then, we hypothesize that increasing automation will be associated with a decrease in local government own source revenues.

A second revenue source comes in the form of 'intergovernmental transfers', where revenue collected at one, typically higher, level of government is transferred to another level of government to be spent. For localities, the state government is the primary source of intergovernmental transfer revenue; only 4 percent of Federal government transfers are made directly to local governments (including school districts). As detailed above, the U.S. is the only Federal democracy that does not have an explicit fiscal equalization scheme to ensure subnational units have comparable public sector resources. Nevertheless, we do expect some increase in transfer revenue, particularly from the State government as the decline in employment and wages should trigger additional transfers pursuant to school finance equalization schemas. Overall, we expect an increase in transfer revenue in response to automation but do not expect intergovernmental transfers to fully compensate for revenues lost as a consequence of automation.

In addition to their own source revenue and intergovernmental transfers, local governments also issue debt to finance public sector spending, particularly for capital investments such as building or renovating schools. Given the negative effect of automation on wages and employment, we might expect local governments to issue more debt in response to compensate for a weakening tax base. Yet local governments are often constrained in their ability to issue debt either because they lack the administrative capacity or legal authority to do so. Moreover, subnational governments in the U.S. are required to balance their budgets, at least over the medium term. We therefore think it unlikely that the rise of automation will prompt localities to issue substantial new debt although it may contribute to higher total outstanding debt levels given the weaker tax base. 
Ultimately, we expect the negative effect of automation on total local government revenues - a large hit to own source revenue coupled with a small uptick in transfer revenue and no meaningful change in debt issuance-will translate into reductions in total direct expenditures. And particularly on spending where local governments play a major role in financing and delivery of public goods, including K-12 education, police, health and public welfare.

Next we describe the data and analytic approach used to test these hypotheses.

\section{Data}

\section{Measuring Automation}

Studies examining the effects of automation have varied in their operationalization of the concept. One group of scholars, focusing on occupation-based measures of automation, have applied a 'routine task index' (RTI) to track changes in the relative routineness of jobs over time (Autor and Dorn 2013, Goos Manning Salomons 2014); however, recent studies have cast skepticism on the validity of comparing RTI across time and place (Haslberger 2021). Others have captured automation through measures of computerization (Kristal 2013), productivity growth (Autor and Salomons 2018), and advancements in robotic arms (Graetz and Michaels, 2018). Yet the most readily applied and accepted measure of automation is the introduction of industrial robots (Acemoglu \& Restreppo 2020). The advantages of using data on industrial robots are that (1) they directly reflect new technologies designed to automate routine tasks, as opposed to occupation-based measures that may be driven by other secular labor market trends, (2) have been established in prior research as reliable predictors of the decline of industrial jobs, and (3) can allow for causal estimates of the impact of automation on local-level outcomes. Moreover, of the various types of automation, it is the use of industrial robots - which displaces a certain class of 
workers concentrated in specific geographies - that is most likely to impact local government finances. For these reasons, we use the introduction of industrial robots as our operationalization of automation.

The primary empirical challenge to estimating the relationship between industrial automation and local government finance is that trends in these two measures may be jointly determined by some third factor: for example, a decline in the working-age population (due to outmigration or selective mortality) may independently lead to increased robot adoption by firms and lower revenues collected by state and local governments. Following A\&R, we address this endogeneity by employing a measure of the predicted commuting zone level increase in industrial robots (per 1,000 workers) we would expect if robot adoption in U.S. industries follows the trajectory seen in European countries. The measure is constructed by interacting 1990 U.S. commuting zone- level data on employment shares across different industries with data on the growth in industrial robots in each of these industries for 5 European countries (Denmark, Finland, France, Italy, and Sweden) which adopted industrial robots earlier than their counterparts in the U.S. This measure is known as a "shift-share instrument" in the econometrics literature (Goldsmith-Pinkham, Sorkin and Swift 2020).

Figure 1 plots the spatial distribution of the automation measure by quartiles. The mean (median) commuting zone experienced a $.46(.42)$ per 1,000 worker increase in industrial robots. Automation was greatest in the industrial Midwest, the U.S. South, and parts of the Northeast and Southwest.

[Insert Figure 1 About Here] 


\section{Measuring Local Fiscal Outcomes}

Public Finance Data: Our primary dependent variables are measures of local government finance. Data are taken from the U.S. Census of Governments, which is conducted every 5 years (in years ending in 2 and 7) to provide a full accounting of state and local government finances. A striking feature of subnational governments in the U.S. is substantial cross-state heterogeneity in the structure of fiscal governance. To permit ready comparison within and between states, we aggregate the finances of all local government units-including counties, towns/townships, school districts, municipalities - to the 'county area'. Aggregating to the county area is common practice in public finance research (Census 2006; see, e.g., Baicker \& Gordon 2006) as it simultaneously accounts for differences in sources of local-level revenue collection and enables proper comparisons of local revenues across place and time. All dollars are per capita, inflation adjusted to 2020 dollars, and log-transformed.

Our main outcome of interest is local government 'own source revenue' which refers to dollars collected by local governments pursuant to taxes, fines and fees levied by local governments. We also examine 'intergovernmental transfer revenue' from the State and Federal governments, separately, which capture direct fiscal transfers from higher levels of government. as well as total outstanding long-term debt and total expenditures. We go on to examine specific categories of local government spending: K-12 education, health, police and public welfare. In doing so, we are able to directly examine how automation affects key social investments made by the local public sector.

School Finance Data: We supplement our analysis of education spending per capita with estimates of per-student revenue and expenditures using school finance data from the National Center for Education Statistics. We aggregate district-level data on per-student revenues and 
expenditures to the county-area by constructing a weighted average based on the number of enrolled students at the start of the school year. In addition to measures of total revenues and expenditures per student, for each county we also have measures of the per-student revenue coming from local sources, state sources and federal sources. This permits us to decompose the effect of automation on school funding from different levels of government.

\section{Analytic Approach}

An additional empirical challenge is how to model the fiscal effect of a commuting zone level change in robot penetration on local revenues when commuting zones cross state lines. Consider the State of Ohio, illustrated in Figure 2 alongside its neighboring states. Ohio contains 88 counties. Those counties are nested within 20 distinct commuting zones. Some of those commuting zones include only counties in the state of Ohio; for example, the commuting zone of Columbus is located in the geographic center of the state and consists of nine counties, all in the state of Ohio. Yet some Ohio counties are part of commuting zones centered in another state; for example, the counties of Belmont and Monroe in the eastern part of the state are part of the commuting zone for Wheeling, West Virginia. At the same time, some commuting zones centered in Ohio contain counties in other states; for example, the Cincinnati commuting zone consists of 12 counties, 6 in the state of Ohio and 6 in the state of Kentucky just across the Ohio river.

[Insert Figure 2 About Here]

We address this empirical challenge by taking counties (and county equivalents) as the building blocks of our dataset. Our analytic sample comprises 3,101 counties, each nested within 
one of 722 commuting zones as well as within one of the 48 contiguous states. ${ }^{2}$ Taking counties as our unit of analysis enables us to estimate the relationship between a commuting zone-level change in automation (our primary 'right hand side variable') and county area change in public finances (our 'left hand side' variables).

Our analytic approach hews closely to that of A\&R (2020), wherein we regress the predicted change in automation in the commuting-zone on the observed change in local government finances aggregated to the county level. For our primary analyses we focus on the effect of increasing automation between 1993 and 2000 on the change in government finances over the decade between 1992 and 2002. This ensures our finance measure starts before and ends after the focal period of robot change. For our primary outcome, we also estimate this relationship over a slightly longer time horizon - regressing the change in automation between 1993 and 2007 on the change in own source revenue between 1992 and 2007-to directly compare our estimates with the wage and employment effects estimated by A\&R (2020).

We examine two different measures of the predicted change in automation: the first captures predicted robot penetration across all industries whereas the second measure excludes trends in the automotive industry. We do so for several reasons. For one, the automotive industry experienced - by far - the largest increase in automation since 1990. Moreover, this growth was concentrated both spatially, primarily in commuting zones in and around the state of Michigan, and temporally with robot adoption accelerating after 2000. In addition to examining two time periods - one that ends in 2000 before this acceleration and one that ends in 2007-we also

\footnotetext{
${ }^{2}$ Alaska and Hawaii are excluded from the analysis due to lack of automation data; the 5 constituent counties (boroughs) of New York City are aggregated to a single fiscal entity; 2007 finance data are missing for Davidson County, TN.
} 
estimate models using a measure of automation that excludes the automotive industry to ensure our results are not being driven by trends specific to this massive industry. Specifically, we estimate:

(1) $\Delta Y_{i, j, s, t 1-t 0}=\alpha_{1} \times \Delta$ Automation $_{j, s, t 1-t 0}+\beta \times$ BaselineChar $_{j, r, t 0}+\theta_{s}+e_{i, j, s, t}$ where $i$ indexes the county, $j$ indexes the commuting zone, $s$ indexes the state, $t 0$ indexes the initial year and $t 1$ indexes the end year. $\Delta Y_{i, j, s, t 1-t 0}$ represents the change in the 'county area' local government finance measure (between 1992 and either 2002 or 2007) and $\Delta$ Automation $_{j, s, t 1-t 0}$ represents the predicted change in the number of industrial robots per 1,000 workers at the commuting zone level (between 1993 and either 2000 or 2007).

$\alpha_{1}$ is our parameter of interest and captures the association between the change in exposure to automation and change in local government finance. Because shift-share instrumental variables strategies are susceptible to bias if the baseline characteristics (here, commuting zone industrial shares in 1990) used to create the instrument are correlated with other baseline characteristics whose subsequent trends may also affect the outcomes of interest (Goldsmith-Pinkham, Sorkin \& Swift 2020), we follow A\&R's preferred specification and adjust rich set of baseline characteristics, including commuting zone demographics (age distribution, race/ethnicity population shares) and socioeconomic characteristics (shares completing high school and college education, share employed in manufacturing, share employed in routine occupations, and exposure to foreign trade). We further include a vector of state fixed effects denoted by $\theta_{s}$; we do so given substantial cross-state differences in the structure of fiscal governance and the mechanical interdependence of state and local government finances. In a first difference framework, inclusion 
of these covariates in the model allows for differential time trends by state and as a function of these baseline commuting zone characteristics.

All models are weighted by county population in the year 1992. To address potential interdependence within states and within commuting zones we cluster standard errors on both geographies.

\section{Findings}

Figure 3 presents local government own source revenue per capita aggregated to the county area for fiscal year 1992, the start of our study period. First note the substantial variation in own source revenues across the U.S., ranging from a low of $\$ 187$ to a high of more than $\$ 5,550$ per capita. Second, notice how state borders are readily visible in this map of U.S. counties, underscoring how the structure of fiscal governance-including the relative intensity of local government revenue collection-varies systematically across states. Local governments in Vermont, for example, collect substantially less in revenue than their counterparts in neighboring states; as Vermont is more fiscally centralized, the state government collects a larger share, and local governments collect a smaller share, of the total revenue collected within the state.

\section{[Insert Figure 3 About Here]}

Figure 4 shows the percentage change in local government own source revenue over the 10 years between 1992 and 2002. Here again we see wide variation across the country, with some areas seeing strong growth whereas others experienced absolute declines in (inflation adjusted) own source revenues. Notably this map reveals counties that saw declining or stagnating revenues over this decade are concentrated in the upper Midwest and Northeast, regions hardest hit by 
deindustrialization. To what extent did the rise of industrial robots contribute to this place-based variation in the trajectory of local government revenues?

[Insert Figure 4 About Here]

Table 1 presents results from our primary specific estimating the effect of increasing automation on local government own source revenue. Panel A presents estimates from our short difference model, where we regress predicted commuting zone change in robot penetration between 1993 and 2000 on the observed change in county area own source revenue per capita between 1992 and 2002. For our measure of predicted robot adoption across all industries, we find automation has a large, negative effect on local government own source revenue. The point estimate implies that every additional robot per 1,000 workers is associated with a 10 percent relative decrease in local government own source revenue. We find a similar effect when we exclude trends in the automotive industry, with the point estimate in Column 2 indicating a 9 percent reduction in local own source revenue for every additional robot per 1,000 workers.

\section{[Insert Table 1 About Here]}

Panel B below repeats this analysis for the longer time horizon, regressing change in robot penetration between 1993 and 2007 on change in local government own source revenue between 1992 and 2007. When using the measure of robot adoption across all industries we find no evidence of an effect of automation on local government finances over this longer 15-year window. We do however continue to find a robust negative effect over this longer time horizon when using the measure that excludes the automotive industry; the estimated coefficient implies a 5 percent relative decrease in local government own source revenue for every additional robot per 1,000 workers. This suggests that the extreme values introduced by robot adoption trends in the automotive industry may be driving the attenuated and imprecisely estimated coefficient in 
Column 1. To further investigate, we re-estimated all models in Table 1 excluding the state of Michigan, home of the automotive industry. Results presented in Appendix Table A1 reveal a robust negative effect of automation on local government own source revenue across all four model specifications, providing further evidence that trends specific to the automotive industry explain the discordant results in Table 1.

Taken together, these findings reveal that the rise of automation led to substantial reductions in local government own source revenue. The estimated effect size for each additional robot per 1,000 workers is large but not unreasonable given A\&R found each robot reduced the overall employment rate by 0.39 percentage points and reduced average wages by 0.77 percentage points. Yet own source revenue is not the only one source of funding for local governments; intergovernmental transfers from the state and, to a lesser extent, federal government often makeup a large fraction of total local government revenues. Local governments also often have the capacity to issue long-term debt obligations that can further boost coffers in the short and medium run.

\section{[Insert Table 2 About Here]}

Table 2 examines the effect of automation on these different sources of local government revenue; here and below we focus on the shorter ten-year time horizon. Column 1 again displays the estimated effect of automation on own source revenue (same as in Panel A of Table 1 above). Column 2 presents the estimated effect on state intergovernmental revenue. The coefficient is positive as expected given schemas that target state dollars to poorer school districts although it is not statistically significant. We also find a positive effect on federal intergovernmental revenue, although the percentage change is off a much smaller baseline figure and again is not statistically distinguishable from zero. We also find no significant relationship between the change in automation and the change in total long-term outstanding debt, not surprising given balance budget 
requirements and other constraints on debt issuance. Column 5 investigates the net effect of these different revenue streams by examining local government expenditures. Here we find that each additional robot per 1,000 workers is associated with a 5 percent relative reduction in local government direct expenditures per capita.

\section{[Insert Table 3 About Here]}

We further explore this impact on expenditures in Table 3 by examining the effect of automation on local government spending in 4 key areas: K-12 education, health and hospitals, police protection and public welfare. We find large, negative and statistically significant effects on direct spending on health \& hospitals and K-12 education: point estimates indicate that every additional robot per 1,000 workers between 1993 and 2000 is associated with a 30 percent relative decline in health and hospital spending per capita and an 8 percent relative decline in K-12 education spending per capita. The estimated coefficients on automation in models predicting change in public welfare and police spending are large and negative but not statistically distinguishable from zero.

An alternative explanation for the decline in K-12 education spending is that automation reduced the relative number of school age children in the county, mechanically reducing K-12 spending per capita but not necessarily K-12 spending per student, the operative margin. We examine this in Table 4 using data on per pupil spending from the National Center for Education Statistics (NCES), again aggregated to the county area. Model results in Column 1 reveal automation led to a 4 percent decrease in per-pupil revenue for each additional robot per 1,000 workers in the commuting zone. Columns 2-4 disaggregate sources of K-12 revenue from the local, state and federal governments, respectively. Consistent with our findings above, the effect of automation on local government K-12 revenue is negative, substantively large and statistically 
significant; the point estimate implies every additional robot per 1,000 workers is associated with an 11 percent decrease in local government K-12 revenue per student. The effect on revenue from state and federal governments is positive but small and statistically nonsignificant, again consistent with the patterns observed above. This increased intergovernmental revenue serves to mitigate the overall hit to education spending — as model 5 reveals, each additional robot per 1,000 between 1993 and 2000 workers is associated with a 3 percent reduction in K-12 per pupil spending between 1992 and 2002.

\section{[Insert Table 4 About Here]}

The findings above reveal that automation negatively impacted communities above and beyond the observed effects on employment and wage levels by also reducing dollars available to fund the public sector. The negative impact of automation on local government health and K-12 spending, in particular, reveals how the negative trends accompanying deindustrialization can be self-reinforcing: fewer good paying jobs leads to less tax revenue and reduced investment in human capital which serves to further reduce the health, well-being and economic potential of the entire community.

\section{Robustness Checks}

The appendix includes results from several robustness checks. One threat to the validity of our analytic approach is differential pre-trends, that is, if areas that experienced larger increases in automation over the study period were already experiencing a decline in local government own source revenue. We test for pretends in Table A2 by regressing the change in automation between 1993 and 2000 on the change in local government own source revenue between 1982 and 1992, the decade prior to the study period. The estimated effect is negative but with large standard errors is statistically indistinguishable from zero. In Column 2 we re-estimate our main model including 
the pre-trend as a covariate; the point estimate and standard error on the automation term are substantively identical to our main results. This provides additional confidence that our findings are not being driven by differential trends in local government finance.

We also examined whether results for the short difference period were being driven by commuting zones that experienced particularly large increases in automation; we continue to find large negative effects of automation on own source revenue after winsorizing the top 1 percent of commuting zones (top 2 percent of counties)—see Table A3 Column 1. Finally, in Table A3 Column 2 we demonstrate our findings are not sensitive to the use of population weights.

\section{Discussion and Conclusion}

Deindustrialization and globalization are often said to generate 'winners' and 'losers'. Welfare state research and policy discourse is perennially engaged with the question of how to best compensate the losers, namely, displaced workers; political economists attribute the rise of populism in the U.S. and elsewhere to a failure to adequately do so (Berman 2021; Rodrik 2018). Our findings reveal that these structural shifts also generate fiscal winners and losers which serves to compound the inequalities between rich and poor people by increasing public sector inequalities between rich and poor places.

Specifically, our results indicate each additional robot per 1,000 workers is associated with a 10 percent decline in local government own-source revenues; losses that are only partially offset by increased intergovernmental transfers. The declining revenues lead directly to declining expenditures on core public services: a 30 percent relative decline in per-capita health and hospital spending and 8 percent relative decline in per-capita K-12 education spending. Together, our findings underscore how rising automation has consequences that go beyond its direct effect on 
displaced workers — the subject of most public discussion and social scientific interest — to shape outcomes for residents of the broader community.

Our findings have several implications for sociological research. First, we provide empirical support for the often invoked yet rarely examined mechanism through which concentrated disadvantage impacts life chances: weakened local public sectors. Although our estimates are specific to the effects of automation-induced deindustrialization, our framework can and should be used to investigate the fiscal effects of other socioeconomic events or trends that shape the spatial distribution of poverty and wealth. Identifying fiscal impacts is essential to decoupling direct effects from indirect or ecological effects and revealing how concentrated disadvantage weakens communities over time and across generations.

Embarking on such work requires knowing where to look and what to look for, fiscally speaking, and may represent an undeveloped but potentially productive intersection between scholars of inequality and the New Fiscal sociology. Detailing how places are fiscally structuredhow human wealth is distributed across a series of semi-nested, spatially defined jurisdictions invested with varying responsibilities and opportunities and authorities to tax and spend-can reveal new patterns of being, novel drivers of place-based disparities. A fiscal sociology of place can detail how a decline in retail sales in one community may affect police budgets in another or why in some states the economic wealth generated in urban areas has positive fiscal effects for distal rural communities whereas in other states it does not.

The most important determinant of whether and to what extent a local economic shock translates into a local fiscal shock is how the responsibility to finance key public sector investments is distributed across and between national, state and local governments. It would be both impractical and counterproductive for policymakers concerned about the negative consequences 
of automation to pursue policies that inhibit technological advancement. In the aggregate, the gains in efficiency and productivity and overall wealth that technology brings are an unqualified good. That the adoption of industrial robots by globally competitive firms leads to a local decline in public sector resources is not the fault of automation per se, but rather the fault of a fiscal system that fails to ensure wealth gains accruing to some places (and some people) are redistributed to those places (and those people) who bear the cost of this technological change.

The tight coupling of community economic decline with community fiscal decline is peculiarly American. And is the result of a specific policy context. In Germany, Canada, Australia and every other wealthy federal democracy, an expressed obligation of the central government is to equalize public sector resources across subnational governments. Although the formulas used to calculate and procedures used to administer these transfer payments may be politically contested, that areas with poorer tax bases should receive compensating fiscal transfers to enable equitable public sector financing (and comparable local tax burdens) is not questioned. Notably, place-based inequalities in taxable wealth or fiscal capacity are of first order interest in studies of developing or less wealthy countries (Prasad and Martin 2014). Yet in the U.S. context, where the gaps between the richest and poorest fiscal units are large and growing, the lack of an explicit equalization policy is rarely invoked as a chief cause of growing place-based disparities. Instead, social scientists, politicians, and the public put blame on local policymakers for failing to adequately fund the public sector, despite the fact that variation in subnational government spending primarily results from variation in fiscal capacity, not variation in policy choices.

Of course, one can argue that fiscal capacity varies as a direct result of those local policy decisions, historical and contemporary. And those conversant in economic theories of public finance may be tempted to go further and argue that inequalities in tax burden and government 
spending are justified: as individuals are free to sort across fiscal jurisdictions, residence in a given locale is taken as revealed preference in favor of the prevailing mix of taxes and public goods (Tiebout 1956). Yet the rise of automation and forces of globalization march on, devastating some communities and enriching others depending on features of place-demography, industry mix, human capital— that are not easily remedied by local policy action. The residents and policymakers of Grand Rapids are no more to blame for their fiscal decline than the residents and policymakers of Silicon Valley, greater New York or the Washington DC area are to credit for their fiscal largess.

Ultimately, ensuring place-based inequality in wealth is not compounded by place-based inequality in public sector resources - and with it, disparities in social outcomes-will require federal policy intervention. To be sure, instantiating a fiscal equalization schema will be politically fraught. And absent a complete overhaul of U.S. Fiscal Federalism, it will be complex to design an equalization program that can be grafted onto the current system. It will be necessary to balance competing aims, chiefly to ensure subnational governments maintain their own fiscal effort in the face of increased intergovernmental transfers, i.e., not use federal dollars to eliminate local tax burdens while maintaining anemic spending. Yet many poor communities in the U.S. are already burdened by high effective tax rates - and in poor states, that often translates into an absolute higher tax burden on poor families (Newman \& O'Brien 2011). Fiscal fairness, then, will require simultaneous consideration of tax effort and social need.

That is not to say state and local governments have no policy recourse. As fiscally sovereign entities, states have the legal authority to shape the structure of fiscal governance within their borders however they see fit. This includes everything from the existence of local government entities — counties, cities, school districts—and their nested structure to their relative role in taxing and spending vis a vis one another and vis a vis the state government. The extreme heterogeneity 
in fiscal structures across states we observe today is the result of disparate histories of place unfolding over centuries, with key aspects of fiscal governance designed in earlier eras with different social imperatives and economic realities. A key empirical project of the New Fiscal Sociology must be to interrogate how these historically conditioned fiscal structures are performing today and what features are implicated in the perpetuation or amplification or mitigation of place-based inequalities. Designing novel fiscal solutions to pressing social problems will benefit from identifying the most impactful and feasible policy changes given the status quo as well as wholesale reimagining of how fiscal jurisdictions are drawn, revenues are extracted, and dollars are spent across places.

Our study has several important limitations. For one, we do not have insight into the spatial distribution of state government spending. It is possible that in some states the decline in local government revenues and expenditures is offset not through increased intergovernmental transfers but via increased state government spending in impacted areas. This is relatively more likely in domains where state and local governments typically share spending responsibilities—-such as for health and public welfare — and less likely in domains such as education and police spending where local government is the primary site of policy action. A second limitation of the current study is that we do not examine local government fiscal policymaking in response to automation. We might expect, for example, local governments to increase tax rates in order to maintain revenue levels in the face of a weakening tax base. For the narrow purposes of our examination of revenue and spending levels, such a policy response would downwardly bias our estimates. But more generally, tracking the impact on the overall tax rate and the distribution of tax incidence in addition to revenue and spending levels is key to assessing the overall impact of automation on local government finance. 
Our empirical approach also limits our ability to explore how aspects of state fiscal structures may moderate the effect of automation on taxing and spending. For example, given the negative impact of automation on employment and wages is concentrated among lower-income households (A\&R 2020), we should expect the impact on revenue to be lower in jurisdictions with relatively more progressive revenue systems. We might also expect other features of fiscal systems such as the degree of fiscal centralization and redistribution within states to influence whether and to what extent a decline in own source revenue translates into an actual decline in public sector expenditures. Our identification strategy leaves us underpowered to test for such heterogeneity across fiscal structures, but this is a generative area for future research engaged in a fiscal sociology of place. 


\section{References}

Acemoglu, Daron, and Pascual Restrepo. 2020. "Robots and Jobs: Evidence from US Labor Markets.” Journal of Political Economy 128(6):2188-2244.

Allen, Michael and John L. Campbell. 1994. "State Revenue Extraction from Different Income Groups: Variations in Tax Progressivity in the United States, 1916-1986." American Sociological Review 59(2)169-86.

Autor, David H. (2015). "Why are there still so many jobs? The history and future of workplace automation." Journal of Economic Perspectives 29(3): 3-30.

Autor, David H., Dorn, D., \& Hanson, G. (2019). When work disappears: Manufacturing decline and the falling marriage market value of young men. American Economic Review: Insights, $1(2), 161-78$.

Autor, David, David Dorn, Gordon Hanson, and Kaveh Majlesi. 2020. "Importing Political Polarization? The Electoral Consequences of Rising Trade Exposure.” American Economic Review 110(10):3139-83. doi: 10.1257/aer.20170011.

Autor, D., \& Salomons, A. (2018). Is Automation Labor Share-Displacing? Productivity Growth, Employment, and the Labor Share. Brookings Papers on Economic Activity.

Baicker, Katherine, and Nora Gordon. 2006. "The Effect of State Education Finance Reform on Total Local Resources." Journal of Public Economics 90(8):1519-35. doi: 10.1016/j.jpubeco.2006.01.003.

Bartik, Timothy J. 2019. Making Sense of Incentives: Taming Business Incentives to Promote Prosperity. W.E. Upjohn Institute. 
Béland, Daniel, and André Lecours. 2014. "Fiscal federalism and American Exceptionalism: Why is there No Federal Equalisation System in the United States?." Journal of Public Policy pp. 303-329.

Berman, Sheri. 2021. "The Causes of Populism in the West." Annual Review of Political Science 24(1):71-88. doi: 10.1146/annurev-polisci-041719-102503.

Biasi, Barbara. School finance equalization increases intergenerational mobility: Evidence from a simulated-instruments approach. No. w25600. National Bureau of Economic Research, 2019.

Beckfield, Jason, and Clare Bambra. "Shorter lives in stingier states: social policy shortcomings help explain the US mortality disadvantage." Social science \& medicine 171 (2016): 30-38.

Bradley, Elizabeth H., Maureen Canavan, Erika Rogan, Kristina Talbert-Slagle, Chima Ndumele, Lauren Taylor, and Leslie A. Curry. 2016. "Variation In Health Outcomes: The Role Of Spending On Social Services, Public Health, And Health Care, 2000-09." Health Affairs 35(5):760-68. doi: 10.1377/hlthaff.2015.0814.

Brady, David. 2009. Rich democracies, poor people: How politics explain poverty. Oxford University Press.

Brady, David, and Ryan Denniston. 2006. "Economic Globalization, Industrialization and Deindustrialization in Affluent Democracies.” Social Forces 85(1):297-329. doi: 10.1353/sof.2006.0117.

Brady, David, and Michael Wallace. 2001 "Deindustrialization and poverty: manufacturing decline and AFDC recipiency in Lake County, Indiana 1964-93." Sociological Forum. Vol. 16. No. 2. 
Brand, Jennie E. "The far-reaching impact of job loss and unemployment." Annual review of sociology 41 (2015): 359-375.

Berger, Thor, and Per Engzell. "Intergenerational Mobility in the Fourth Industrial Revolution."(2020. Working Paper, Open Science Foundation.

Browning, M., and Heinesen, E. (2012) "Effect of job loss due to plant closure on mortality and hospitalization." Journal of health economics 31(4), 599-616.

Case, A., and Deaton, A. (2017). "Mortality and morbidity in the 21st century." Brookings Papers on Economic Activity 2017(1): 397-476.

Census Bureau 2006. "Historical Overview of U.S. Census Bureau Data Collection Activities About Governments: 1850 to 2005.” $<$ https://www.census.gov/history/www/reference/publications/publications_governments.html> Accessed September 2021.

Connor, Dylan Shane, and Michael Storper. "The changing geography of social mobility in the United States." 2020. Proceedings of the National Academy of Sciences 117(48): 3030930317.

Chetty, Raj, and Nathaniel Hendren. "The impacts of neighborhoods on intergenerational mobility I: Childhood exposure effects." The Quarterly Journal of Economics 133.3 (2018): 11071162.

Chetty, Raj, Nathaniel Hendren, and Lawrence F. Katz. "The effects of exposure to better neighborhoods on children: New evidence from the Moving to Opportunity experiment." American Economic Review 106.4 (2016): 855-902. 
Esping-Andersen, Gosta. 1990. The three worlds of welfare capitalism. Princeton University Press

Feler, Leo, and Mine Z. Senses. 2017. "Trade shocks and the provision of local public goods." American Economic Journal: Economic Policy 9(4): 101-43.

Fort, Teresa C., Justin R. Pierce, and Peter K. Schott. "New perspectives on the decline of US manufacturing employment." Journal of Economic Perspectives 32.2 (2018): 47-72.

Ganong, P., \& Shoag, D. (2017). Why has regional income convergence in the US declined?. Journal of Urban Economics, 102, 76-90.

Goldsmith-Pinkham, P., Sorkin, I., Swift, H. (2020). "Bartik Instruments: What, When, Why, and How," American Economic Review, 110(8), 2586-2624.

Graetz, Georg, and Guy Michaels. 2018. "Robots at Work." The Review of Economics and Statistics 100(5):753-68. doi: 10.1162/rest_a 00754.

Haslberger, Matthias. 2021. "Rethinking the Measurement of Occupational Task Content." The Economic and Labour Relations Review 10353046211037096. doi: $\underline{10.1177 / 10353046211037095 .}$.

Hoxby, Caroline M. 2001. "All school finance equalizations are not created equal." The Quarterly Journal of Economics 116(4): 1189-1231.

Jackson, C. Kirabo, Rucker C. Johnson, and Claudia Persico. "The effects of school spending on educational and economic outcomes: Evidence from school finance reforms." The Quarterly Journal of Economics 131.1 (2016): 157-218. 
Kollmeyer, Christopher. 2009. “Explaining Deindustrialization: How Affluence, Productivity Growth, and Globalization Diminish Manufacturing Employment.” American Journal of Sociology 114(6):1644-74.

Kollmeyer, Christopher, and Florian Pichler. 2013. "Is Deindustrialization Causing High Unemployment in Affluent Countries? Evidence from 16 OECD Countries, 1970-2003.” Social Forces 91(3):785-812. doi:10.1093/sf/sos184.

Kristal, Tali. 2013. “The Capitalist Machine: Computerization, Workers' Power, and the Decline in Labor's Share within U.S. Industries.” American Sociological Review 78(3):361-89. doi: $\underline{10.1177 / 0003122413481351 .}$.

Manduca, Robert A. 2019. "The Contribution of National Income Inequality to Regional Economic Divergence" Social Forces. 98(2): 622-648

Martin, Isaac William, Ajay K. Mehrotra, and Monica Prasad, eds. 2009. The new fiscal sociology: Taxation in comparative and historical perspective. Cambridge University Press.

Martin, Isaac William \& Monica Prasad. 2014. "Taxes and Fiscal Sociology.” Annual Review of Sociology. 40: 331-345.

Massey, Douglas S. 1990. "American apartheid: Segregation and the making of the underclass." American journal of sociology 96.2: 329-357.

Massey, Douglas, and Nancy A. Denton. 1993. American apartheid: Segregation and the making of the underclass. Harvard university press.

McCabe, Joshua T. 2017. "Federalism in Blue and Red". National Affairs. Summer Edition $<$ https://www.nationalaffairs.com/publications/detail/federalism-in-blue-and-red $>$ 
Montez, Jennifer Karas, Hayward, M. D., \& Zajacova, A. (2019). Educational disparities in adult health: US States as institutional actors on the association. Socius, 5 DOI: https://doi.org/10.1177/2378023119835345

Montez, Jennifer Karas, Beckfield, J., Cooney, J. K., Grumbach, J. M., Hayward, M. D., Koytak, H. Z., Woolf, S. H. \& Zajacova, A. (2020). US state policies, politics, and life expectancy. The Milbank Quarterly, 98(3), 668-699.

Newman, Katherine S. \& Rourke L. O'Brien. 2011. Taxing the Poor: Doing damage to the truly disadvantaged. University of California Press.

Nunn, Jay and Ryan Shambaugh. 2018. "Place-Based Policies for Shared Economic Growth.” Brookings Institution Press. (https://www.brookings.edu/multi-chapter-report/place-basedpolicies-for-shared-economic-growth/)

O’Brien Rourke, Elizabeth F. Bair and Atheendar S. Venkataramani. Forthcoming 2021. "Death by Robots? Automation and Working Age Mortality in the United States” Demography.

Pattillo, Mary. 2013. Black picket fences: Privilege and peril among the black middle class. University of Chicago Press.

Prasad, Monica. 2018. "Problem-Solving Sociology." Contemporary Sociology 47(4): 393-398.

Russo, John, and Sherry Lee Linkon. "The social costs of deindustrialization." Manufacturing a better future for America (2009): 183-216.

Rodrik, Dani. 2018. "Populism and the economics of globalization." Journal of international business policy $1.1: 12-33$.

Sampson, Robert J. 2019. "Neighbourhood Effects and beyond: Explaining the Paradoxes of Inequality in the Changing American Metropolis." Urban Studies 56(1):3-32. doi: $10.1177 / 0042098018795363$. 
Sampson, Robert J. "Moving to inequality: Neighborhood effects and experiments meet social structure." American journal of sociology 114.1 (2008): 189-231.

Seltzer, N. (2020). The economic underpinnings of the drug epidemic. Social Science and Medicine-Population Health DOI: https://doi.org/10.1016/j.ssmph.2020.100679

Sharkey, Patrick. 2008. “The Intergenerational Transmission of Context.” American Journal of Sociology 113(4):931-69. doi: 10.1086/522804.

Sharkey, Patrick, and Jacob W. Faber. "Where, when, why, and for whom do residential contexts matter? Moving away from the dichotomous understanding of neighborhood effects." Annual review of sociology 40 (2014): 559-579.

Sullivan, Daniel, and Till von Wachter. 2009. "Job Displacement and Mortality: An Analysis Using Administrative Data*." The Quarterly Journal of Economics 124(3):1265-1306. doi: $\underline{10.1162 / \text { qjec.2009.124.3.1265. }}$.

Tax Policy Center. 2021. Briefing Book on Federal Grants. $<$ https://www.taxpolicycenter.org/briefing-book/what-types-federal-grants-are-made-stateand-local-governments-and-how-do-they-work $><$ Accessed July 2021 $>$

Tiebout, Charles M. 1956. "A pure theory of local expenditures." Journal of political economy 64(5): 416-424.

Venkataramani, A. S., Bair, E. F., O’Brien, R. L., \& Tsai, A. C. (2020). Association between automotive assembly plant closures and opioid overdose mortality in the United States: a difference-in-differences analysis. JAMA Internal Medicine, 180(2), 254-262.

Wilson, William Julius. 1996. When work disappears: The world of the new urban poor. New York: Knopf. 
Wilson, William Julius. 1987 "The Truly Disadvantaged: The Inner City, the Underclass, and Public Policy." University of Chicago Press. 


\section{Tables and Figures}

Table 1. Effect of Automation on Local Government Own Source Revenue

Panel A. Change in Local Gov Finances 1992-2002 on Predicted Change in Robot Penetration 1993-2000 (Short Difference)

\begin{tabular}{|c|c|c|}
\hline Predicted Change Automation (93-00) & $\begin{array}{c}\text { All Industries } \\
-0.1027 * * \\
(0.0337)\end{array}$ & $\begin{array}{c}\text { Excluding Auto } \\
-0.0883^{* *} \\
(0.0291)\end{array}$ \\
\hline \multicolumn{3}{|c|}{ Panel B. Change in Local Gov Finance 1992-2007 on Predicted Change in Robot Penetration 1993-2007 (Long Difference) } \\
\hline Predicted Change Automation (93-07) & $\begin{array}{c}\text { All Industries } \\
-0.0244 \\
(0.0236)\end{array}$ & $\begin{array}{c}\text { Excluding Auto } \\
-0.0469 * * \\
(0.0161)\end{array}$ \\
\hline $\begin{array}{r}\mathrm{N} \\
\mathrm{R}-\mathrm{sq}\end{array}$ & $\begin{array}{l}3100 \\
0.223\end{array}$ & $\begin{array}{l}3100 \\
0.224\end{array}$ \\
\hline
\end{tabular}

Notes: Standard errors in parentheses $+\mathrm{p}<.10,{ }^{*} \mathrm{p}<.05,{ }^{* *} \mathrm{p}<.01$; Models weighted by county population in 1992; Standard errors clustered on State and Commuting Zone; All models include State Fixed Effects and Covariates as detailed in EQ1 
Table 2. Effect of Automation on Local Government Finances 1992-2002

(1)

Own Source Rev

$-0.1027 * *$

(0.0337)

3101

0.276

(2)

(3)

Fed IG

Predicted Change in Automation

$\mathrm{N}$

R-sq

State IG Rev

Rev

0.0209

0.2205

(0.0456)

(0.1438)

3101

0.147

Outstanding Debt

(4)

(5)

Notes: Standard errors in parentheses $+\mathrm{p}<.10,{ }^{*} \mathrm{p}<.05,{ }^{* *} \mathrm{p}<.01$; Models weighted by county population in 1992; Standard errors clustered on State and Commuting Zone; All models include State Fixed Effects and Covariates as detailed in EQ1 
Table 3. Effect of Automation on Local Government Direct Expenditures by Category 1992-2002

\begin{tabular}{|c|c|c|c|c|}
\hline Predicted Change in Automation & (1) & (2) & (3) & (4) \\
\hline \multirow{3}{*}{ Predicted Change in Automation } & K-12 Educ & Health \& Hospitals & Police & Public Welfare \\
\hline & $-0.0840 * *$ & $-0.2993+$ & -0.0468 & -0.0667 \\
\hline & $(0.0284)$ & $(0.1658)$ & $(0.0412)$ & $(0.1596)$ \\
\hline $\mathrm{N}$ & 3101 & 3101 & 3101 & 3101 \\
\hline R-sq & 0.169 & 0.143 & 0.143 & 0.204 \\
\hline
\end{tabular}

Standard errors in parentheses $+\mathrm{p}<.10,{ }^{*} \mathrm{p}<.05,{ }^{* *} \mathrm{p}<.01$; Models weighted by county population in 1992; Standard errors clustered on State and Commuting Zone; All models include State Fixed Effects and Covariates as detailed in EQ1 
Table 4. Effect of Automation on K-12 Per Pupil Revenues \& Expenditures ('92-02)

(1) (2)

Total Revenue Local Revenue
(3)
(4)

(5)

Total Expenditure

Predicted Change in Automation $-0.0370^{*}$

$-0.1126^{*}$

Federal Revenue

0.0419

$-0.0344+$

$(0.0154)$

$(0.0443)$

$(0.0330)$

$(0.0314)$

$(0.0185)$

$3092-3092-3092$

3092

$0.722 \quad 0.756$

0.314

0.535

Standard errors in parentheses $+\mathrm{p}<.10,{ }^{*} \mathrm{p}<.05,{ }^{*} \mathrm{p}<.01$; Models weighted by county population in 1992; Standard errors clustered on State and

Commuting Zone; All models include State Fixed Effects and Covariates as detailed in EQ1 
Figure 1. Exposure to automation across U.S. Commuting Zones, 1993-2000

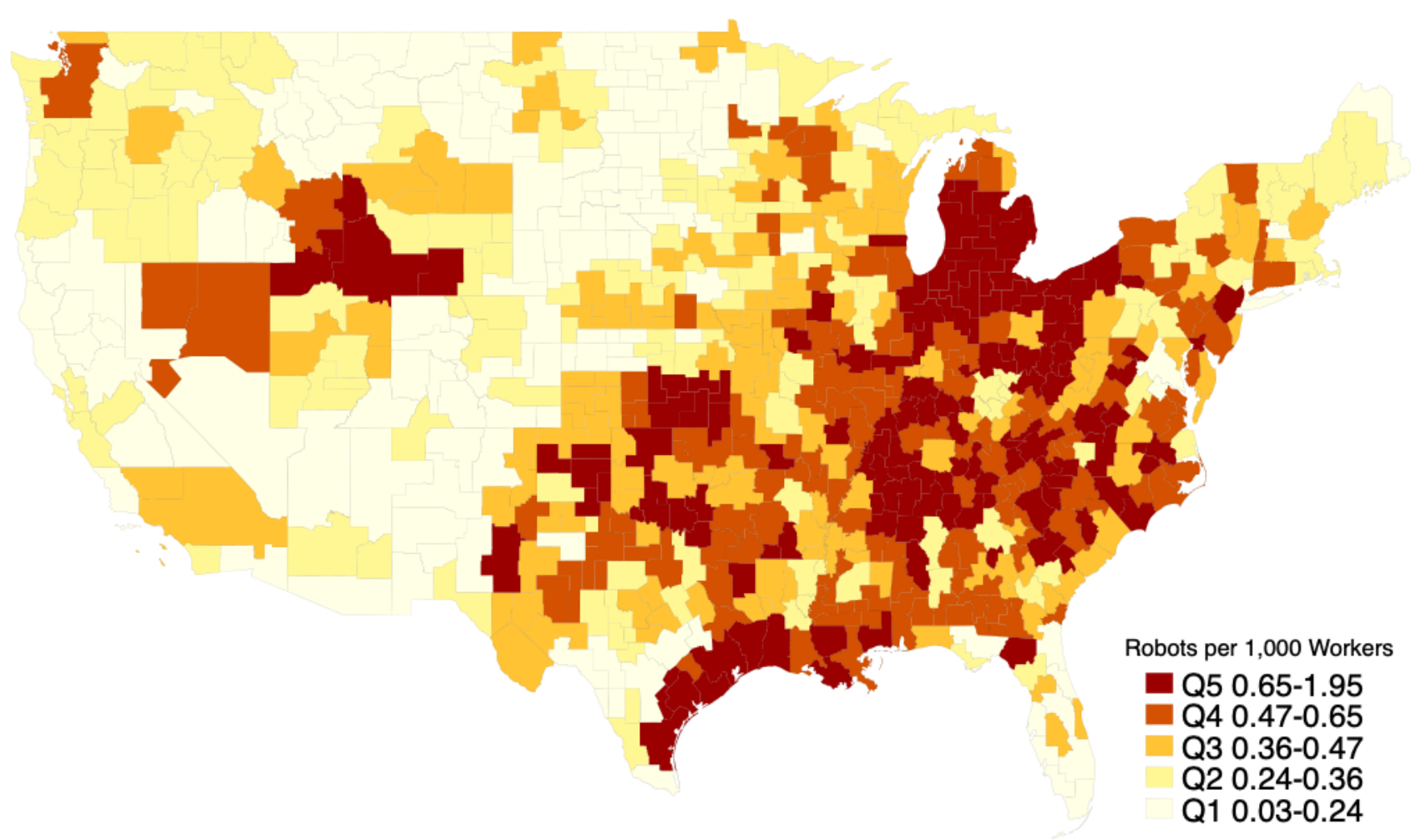

Notes: Figure maps quintiles of commuting-zone-level exposure to automation, as measured by change in the number of industrial robots per 1,000 workers, 1993-2000. Map shows county borders. Data were obtained from Acemoglu and Restrepo (2020). 
Figure 2. Commuting Zones (black lines) and Counties (white lines) in Ohio and neighboring states.

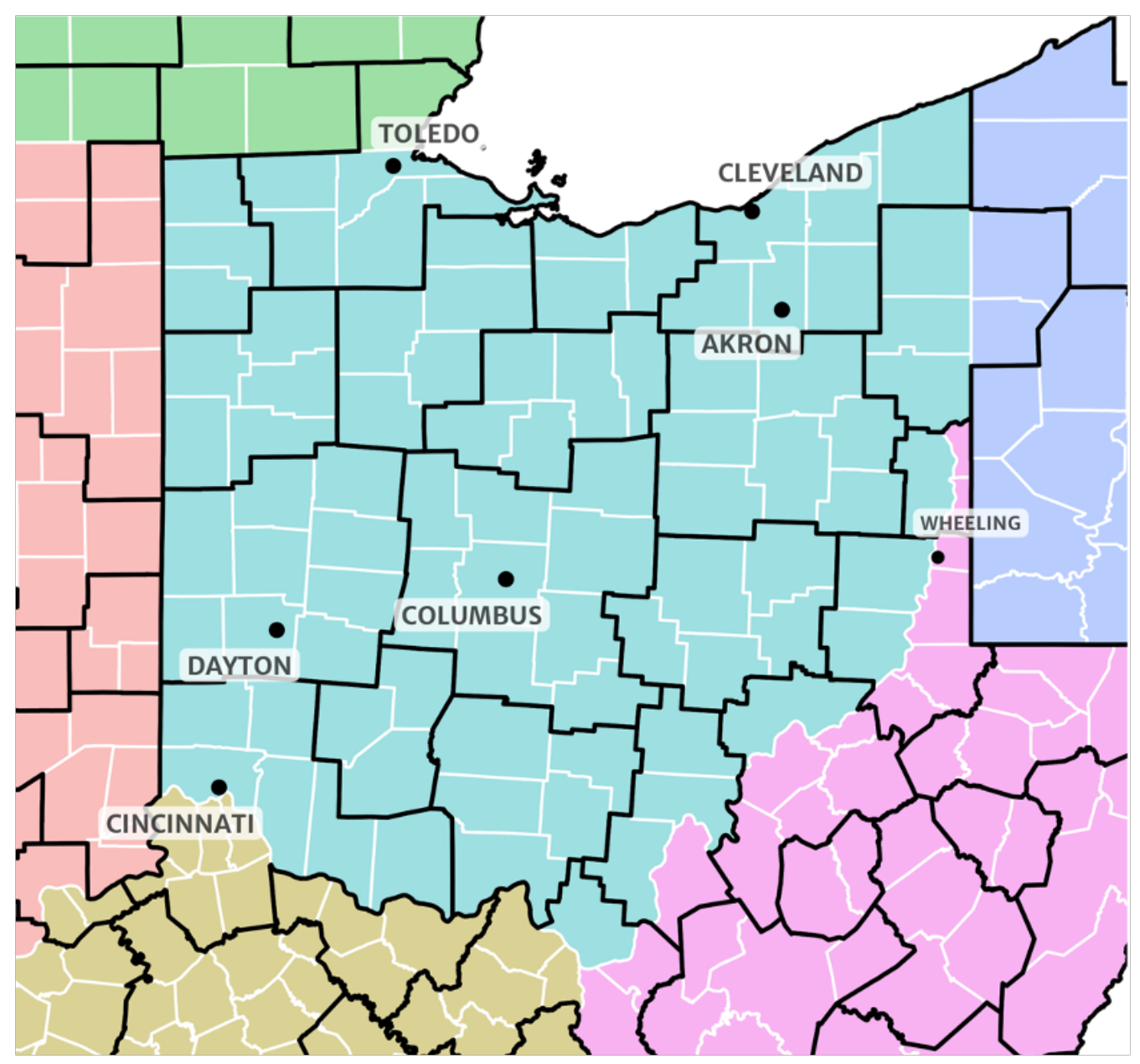


Figure 3. Local Government Own Source Revenue Per Capita in 1992

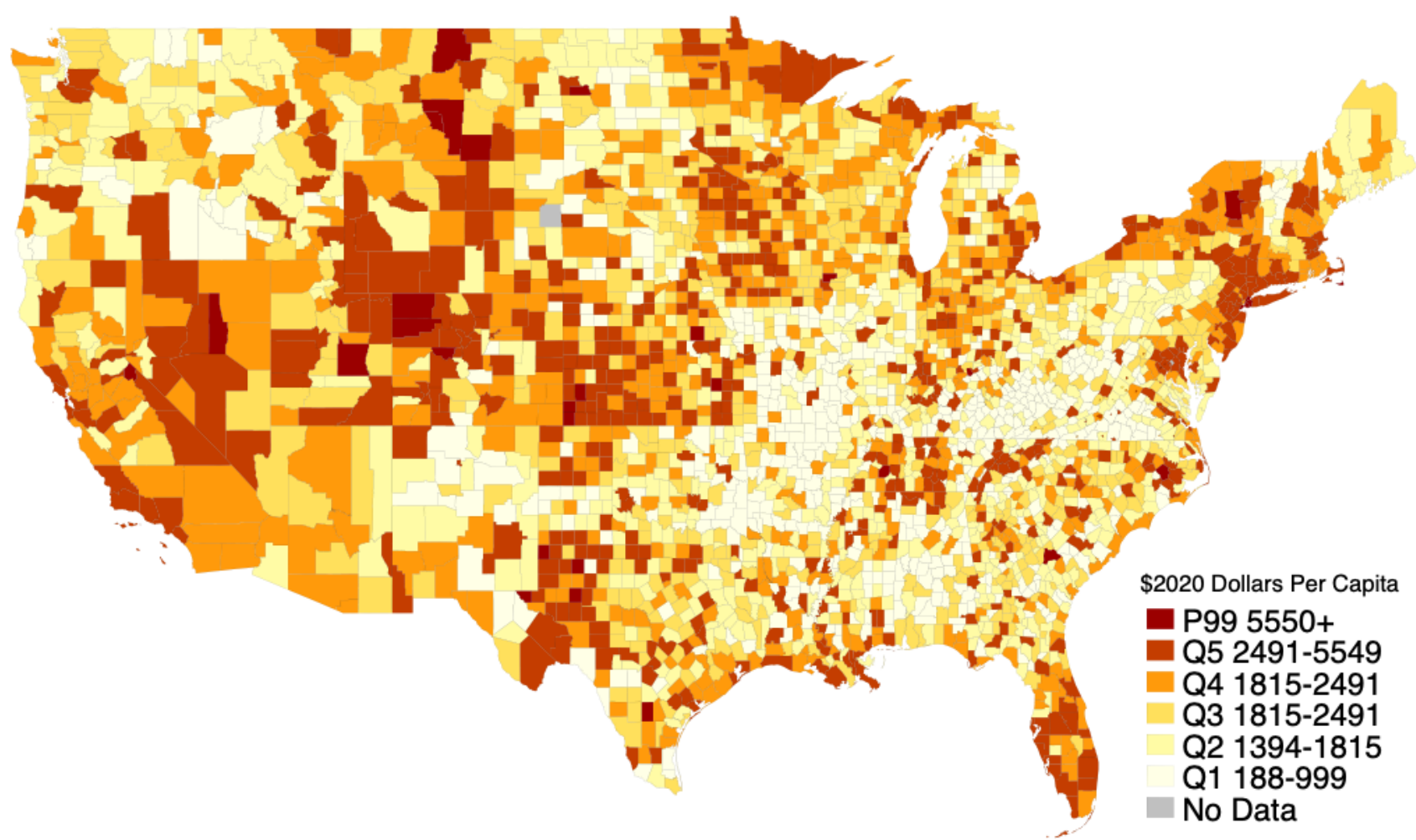

Notes: Figure maps quintiles of local government own source revenue per capita aggregated to the 'county area'; Q5 corresponds to 80-99 percentile, top 1\% shown separately. All dollar values per capita and inflation adjusted to \$2020. 
Figure 4. Change in Local Government Own Source Revenue Per Capita in 1992-2002

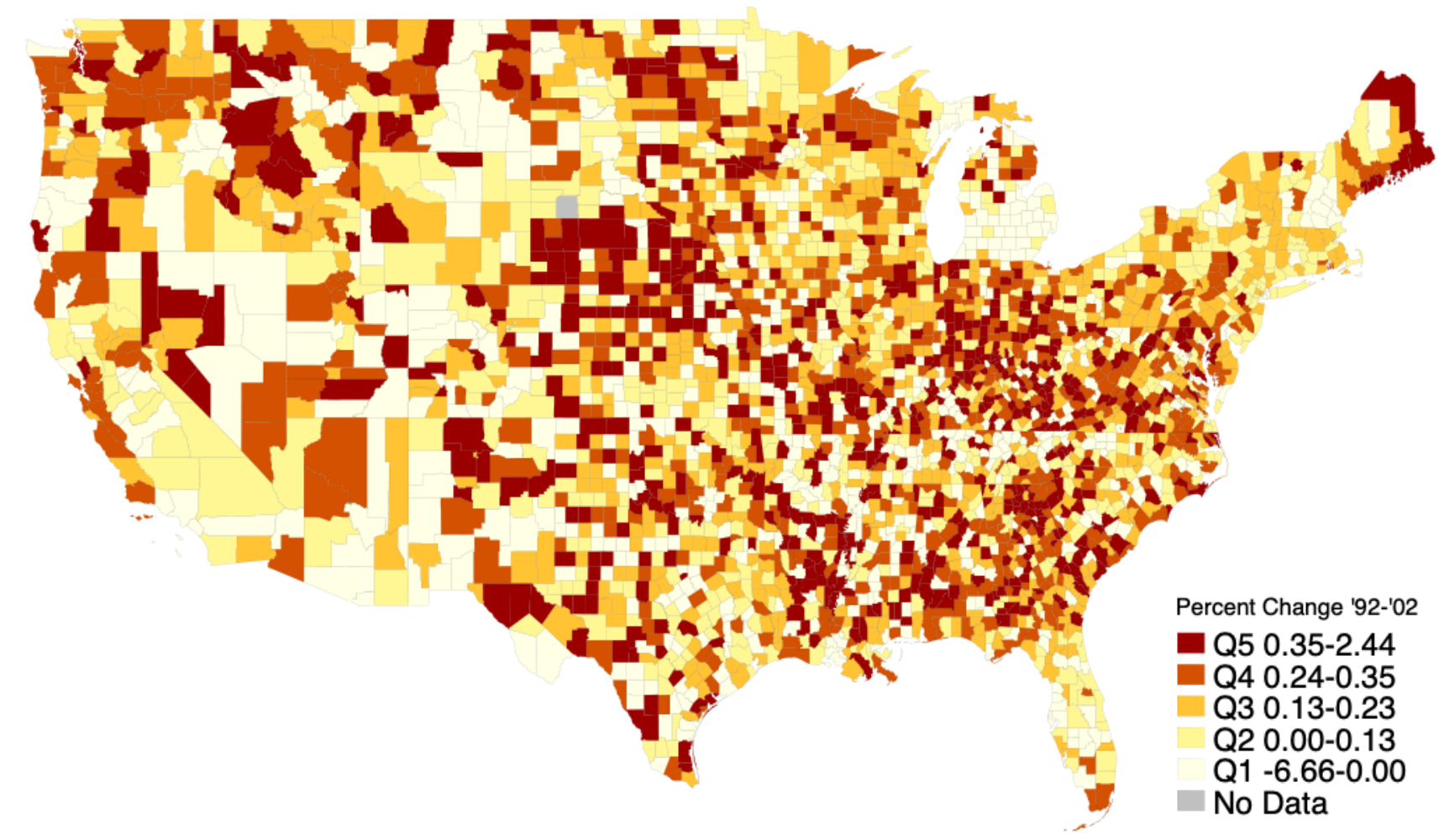

Notes: Figure maps quintiles of percentage change in local government own source revenue aggregated to the 'county area' between 1992 and 2002. All dollar values per capita and inflation adjusted to \$2020. 


\section{Appendix Tables}

Table A1. Effect of Automation on Local Government Own Source Revenue (Excluding Michigan)

Panel A. Change in Local Gov Finances 1992-2002 on Predicted Change in Robot Penetration 1993-2000 (Short Difference)

\begin{tabular}{rcc} 
& All Industries & Excluding Auto \\
Predicted Change Automation (93-00) & $-0.0978^{* *}$ & $-0.0769^{*}$ \\
& $(0.0358)$ & $(0.0322)$ \\
\hline N & 3018 & 3018 \\
R-sq & 0.261 & 0.260
\end{tabular}

Panel B. Change in Local Gov Finance 1992-2007 on Predicted Change in Robot Penetration 1993-2007 (Long Difference)

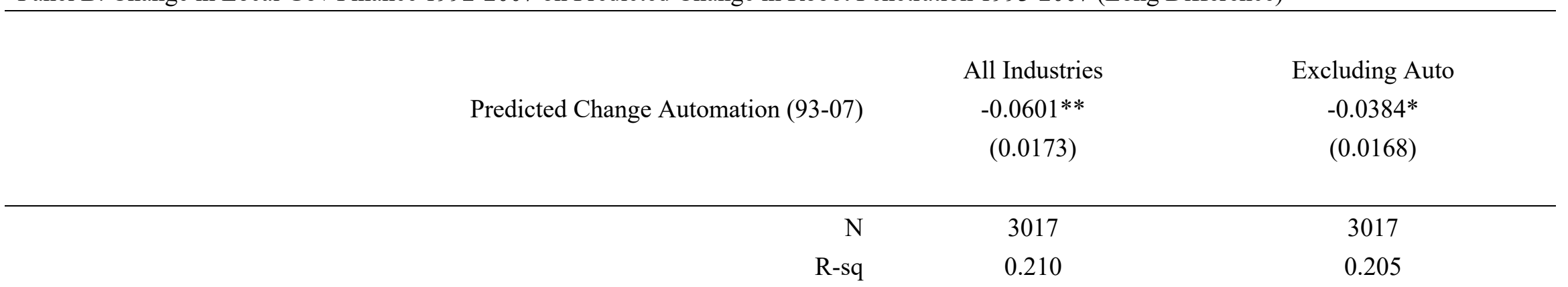

Notes: Standard errors in parentheses $+\mathrm{p}<.10,{ }^{*} \mathrm{p}<.05,{ }^{* *} \mathrm{p}<.01$; Models weighted by county population in 1992; Standard errors clustered on State and

Commuting Zone; All models include State Fixed Effects and Covariates as detailed in EQ1 
Table A2. Robustness Checks: Pre-trends Analysis

Own Source Rev ('82-92)

Predicted Change Automation ('93-00)

Change Own Source Rev ‘82-92
(1)

(2)

Own Source Rev ('92-02)

$-0.0406$

$(0.0428)$
$-0.1132 * *$

(0.0342)

$-0.2521 * * *$

$(0.0423)$
$\mathrm{N}$

R-sq
3100

0.253

0.317

Notes: Standard errors in parentheses $+\mathrm{p}<.10,{ }^{*} \mathrm{p}<.05, * * \mathrm{p}<.01$; Models weighted by county population in 1992; Standard errors clustered on State and Commuting Zone; All models include State Fixed Effects and Covariates as detailed in EQ1 
Table A3. Robustness Checks: Remove Heavily Automated CZs; Unweighted

\begin{tabular}{lcc}
\hline & $(1)$ & $(2)$ \\
& Winsorized Top 2\% & Unweighted \\
& Own Source Rev & Own Source Rev \\
Predicted Change in Automation & $-0.1153^{* *}$ & $-0.0768+$ \\
& $(0.0408)$ & $(0.0385)$ \\
\hline $\mathrm{N}$ & & 3101 \\
$\mathrm{R}-\mathrm{sq}$ & 3101 & 0.080 \\
\hline
\end{tabular}

Notes: Standard errors in parentheses $+\mathrm{p}<.10,{ }^{*} \mathrm{p}<.05,{ }^{*} \mathrm{p}<.01$; Models weighted by county population in 1992; Standard errors clustered on State and Commuting Zone; All models include State Fixed Effects and Covariates as detailed in EQ1 